\title{
Experimental calibration of underground heat transfer models under a winery building in a rural area
}

The Mining-Geology-Petroleum Engineering Bulletin UDC: 622.1:620.9

DOI: 10.17794/rgn.2017.3.4

Original scientific paper

\author{
Francesco Tinti'; Alberto Barbaresi²; Marco Ferrari'; Mohamed Elkarmoty'; \\ Daniele Torreggiani² ${ }^{2}$ Patrizia Tassinari $^{2}$; Stefano Bonduà ${ }^{1}$ \\ ${ }^{1}$ Department of Civil, Chemical, Environmental and Materials Engineering, University of Bologna, via Terracini 28, 40131 Bologna, Italy \\ ${ }^{2}$ Department of Agricultural Sciences, University of Bologna, viale Fanin 44, 40127 Bologna, Italy
}

\begin{abstract}
Ground temperature and hydrogeological conditions are key parameters for many engineering applications, such as the design of building basements and underground spaces and the assessment of shallow geothermal energy potential. Especially in urban areas, in the very shallow depths, it is difficult to find natural undisturbed underground thermal conditions because of anthropic interventions. The assessment of underground behaviour in disturbed conditions will become more and more relevant because of increasing awareness to energy efficiency and renewable energy topics. The purpose of this paper is to show a three-dimensional representation - based on models calibrated on experimental data - of the underground thermal behaviour affected by a building in a rural area in Italy. Temperature varies in space and time and it depends on ground, climate and building characteristics, and all these parameters are taken into account by the seasonal periodic modelling implemented. The results obtained in a context of low urbanization indirectly suggest the importance of these effects in dense urban areas; taking greater account of these aspects could lead to improvements in the design of underground spaces and geo-exchanger fields for geothermal energy exploitation.
\end{abstract}

Keywords

Thermal impact of buildings, ground temperature, shallow geothermal energy, heat transfer via the ground.

\section{Introduction}

The ground temperature at different depths is closely related to the geothermal heat flow of endogenous origin. However, in shallow layers, its contribution is limited, and the three-dimensional temperature distribution is a result of interrelation between many factors, which are:

- seasonal climatic variations,

- soil thermal properties,

- hydrogeological properties,

- urbanization and related Urban Heat Island (UHI) effect,

- snow cover,

- geothermal heat flow.

All the parameters are spatially distributed at a different scale. Temperature suffers from significant variations along depth according to the change of thermogeological variables of the ground and fluids and it is also time-dependent, since parameters change across time.

The topic of knowledge of underground temperature distribution is a matter of investigation by many authors.

Corresponding author: Francesco Tinti

francesco.tinti@unibo.it
The fields of application are various and they generally fall under the following three categories:

- energy efficiency and building insulation methods, for the minimization of heat losses via the ground (e.g. Claesson and Hagentoft, 1991; Hagentoft and Claesson, 1991; Rees et al., 2000),

- agricultural engineering and goods conservation techniques, for new design criteria of cellars and underground spaces (e.g. Mazarron et al., 2012; Barbaresi et al., 2014),

- renewable energy and geoengineering, for the improvement of shallow geothermal resources assessment and the maximization of heat recovery (e.g. Bandos et al., 2009; Kurevija and Vulin, 2010).

Energy geo-structures deal with all the above-mentioned aspects, since the energy rates exploitation and the working temperatures for air conditioning of buildings are either dependent on natural subsoil conditions, building heat losses via the ground and heat transfer and storage in underground spaces (Adam and Markiewicz, 2009; Barla and Perino, 2015).

The replacement of the natural soil and vegetation by artificial surfaces always increases the air and subsurface temperature around a building throughout the year and this is caused by: the indirect solar heating by urban 
structures, the building heat losses and the land use change (Bornstein, 1968; Ferguson and Woodbury, 2004; Mandanici et al., 2016). At a district or city level, this phenomenon is called the Urban Heat Island effect (Landsberg, 1981).

Several experimental studies have demonstrated that the heat loss from buildings increases the subsurface temperature by several degrees and this thermal impact is more persistent in the subsurface rather than in the air because of slower heat transfer underground (Huang et al, 2009).

Heat loss from an individual building results in the generation of a bulb-shaped volume of subsurface temperatures higher than natural ones without any building influence. Experimental measures on groundwater temperature in urban areas were aimed to investigate this phenomenon and were performed all over the world, for example in Canada (Ferguson and Woodbury, 2007), Germany (Zhu et al., 2010; Menberg et al., 2013), Ireland (Allen et al., 2003), Japan (Taniguchi et al., 2007), Turkey (Yalcin and Yetemen, 2009), United Kingdom (Headon et al., 2009) and Finland (Arola and KorkkaNiemi, 2014). In the presence of highly urbanized zones, temperature values are higher, from 2.0 to $5.0^{\circ} \mathrm{C}$, than surroundings were generally found.

This paper presents a contribution to this research field. An experimental campaign of underground temperature affected by the presence of a building with an underground cellar was performed in the countryside of Bologna, Italy. Underground thermal modelling and building heat transfer via the ground were calibrated with the experimental measures to model the bulbshaped volume of subsurface temperature below and around the building itself.

An in-house software code is used to assign, to each location and time step inside the case study area, the value of underground temperature. The space-time varying sinusoidal behaviour of heat transfer via the ground is finally represented in four dimensions $(x, y, z, t)$.

\section{Methods, techniques, material studied and area description}

\subsection{Heat transfer via the ground}

The basic equation for defining the vertical distribution assessment of temperature $\left(T_{g}\right)$ is a function of the ambient temperature wave, the thermal properties of the ground layers and the geothermal gradient (Kusuda and Achebach, 1965). Since all the variables entering the function are regionalized, the target variable is four dimensional, varying in space $(x, y, z)$ and time $(t)$. Having $T_{g}$ a sinusoidal behaviour, the year is usually chosen as a wave period.

Equation 1 summarizes the well-known distribution of temperatures in the subsoil (Baggs, 1985).

$$
\begin{gathered}
T_{g}(x, y, z, t)=T_{m e}(x, y)-1.07 \cdot s_{h} \cdot A_{e}(x, y) . \\
\cdot \exp \left[-z \cdot \sqrt{\left(\frac{\pi}{365 \cdot \alpha(x, y, z)}\right)}\right] \\
\cdot \cos \left[\frac{2 \cdot \pi}{365} \cdot\left(t-t_{T_{0}}(x, y)-\frac{z}{2} \cdot \sqrt{\frac{365}{\pi \cdot \alpha(x, y, z)}}\right)\right]+ \\
+\frac{h(x, y)}{\lambda(x, y, z)} \cdot z
\end{gathered}
$$

Where:

$T_{g} \quad$ - space-time varying underground temperature $\left({ }^{\circ} \mathrm{C}\right)$,

$T_{m e}$ - annual surface average temperature $\left({ }^{\circ} \mathrm{C}\right)$,

$s_{h} \quad$ - vegetation and shading coefficient (varying from 1 - bare ground in full sun to $0.22-100 \%$ vegetation cover) (-) (Popiel et al., 2001),

1.07 - correction parameter, specific for the northern hemisphere (-),

$A_{e} \quad$ - annual surface wave amplitude $\left({ }^{\circ} \mathrm{C}\right)$,

$t_{T 0} \quad$ - time at minimum temperature (days),

$a$ - equivalent thermal diffusivity ( $\mathrm{m}^{2} /$ days),

$h$ - geothermal heat flow $\left(\mathrm{W} / \mathrm{m}^{2}\right)$,

$l$ - equivalent thermal conductivity $(\mathrm{W} /(\mathrm{m} \cdot \mathrm{K}))$.

According to the International Standard ISO 13370 (ISO, 2007), the space-time varying behaviour of the heat flow in the ground should be taken into account in the design phase of a building. Equation 2 shows the periodic component of the heat flow rate between building and the ground, depending on the variations of temperature throughout the year, both outside and inside the building.

$\Phi(x, y, t)=H_{g}(x, y) \cdot\left(T_{m i}(x, y)-T_{m e}(x, y)\right)-$

$-H_{p i}(x, y) \cdot A_{i}(x, y) \cdot \cos \left(2 \pi \cdot \frac{t-t_{T 0}(x, y)+a(x, y)}{365}\right)+$

$+H_{p e}(x, y) \cdot A_{e}(x, y) \cdot \cos \left(2 \pi \cdot \frac{t-t_{T 0}(x, y)-b(x, y)}{365}\right)$

Where:

$F$ - space-time varying heat flow rate (W),

$T_{m i}$ - annual internal average temperature $\left({ }^{\circ} \mathrm{C}\right)$,

$A_{i}$ - annual internal wave amplitude $\left({ }^{\circ} \mathrm{C}\right)$,

$H_{g}$ - steady-state ground heat transfer coefficient between internal and external environments $(\mathrm{W} / \mathrm{K})$,

$H_{p i}$ - periodic heat transfer coefficient related to internal temperature variations $(\mathrm{W} / \mathrm{K})$,

$H_{p e}$ - periodic heat transfer coefficient related to external temperature variations $(\mathrm{W} / \mathrm{K})$, 
$a$ - time lead of the heat flow cycle compared with that of the internal temperature (days),

$b$ - time lag of the heat flow cycle compared with that of the external temperature (days).

The heat flow rate spatially varies according to the shape and volume of the building zones, the different insulation materials, the floor types (slab-on-ground, suspended, basement floor) and the presence of underground cellars and other empty spaces.

Based on experimental calibration, models of underground temperature affected by the presence of a building, at different locations, were obtained by Tinti et al. (2015). Table 1 reports a list of the models (Equation 3, Equation 4, and Equation 5).

\subsection{Case study winery}

The case study considered for this work deals with a building in a rural area in the countryside Bologna (Italy). It consists of a two-storey building with an underground wine-ageing room (see Figure 1). The bearing is $32^{\circ}$ North-East. The main parameters of the building are reported in Table 2.

Weather and building temperature data for the case study are shown in Table 3.

A weather station located $100.0 \mathrm{~m}$ away from the building collected the main weather data and allowed to calculate the main ambient data (mean $T_{m}$ and amplitude $A$ ). The two values are in line with the climate of Bo-

Table 1: Models of underground temperature affected by the presence of a building.

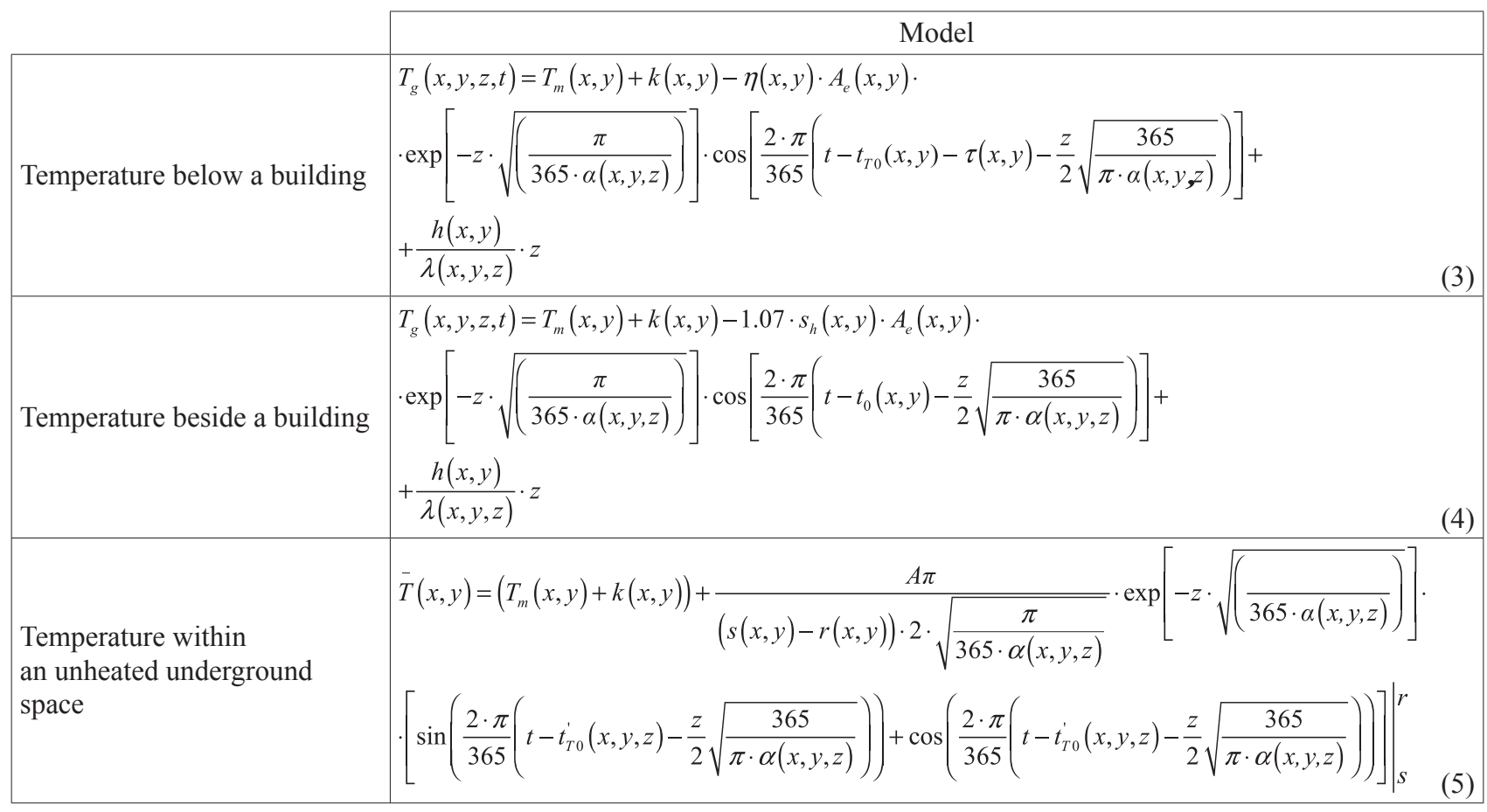

Where:

$\bar{T} \quad$ - uniform temperature inside the unheated underground space $\left({ }^{\circ} \mathrm{C}\right)$,

$k, \eta, t$ - parameters identifying the specific building insulation potential; they vary according to the building geometry and shape and they are dependent on the heat transfer expressed by Equation $2\left({ }^{\circ} \mathrm{C}\right),(-)$, (days),

$s, r$ - lower and upper limit of the unheated underground space $(\mathrm{m})$.

$V B A{ }^{\circledR}$ was used to develop the in-house software code (hereinafter called Tzone 1.0) to assign to each underground point $(x, y, z, t)$ the correct equation and model parameters, according to its position with respect to the building, while Voxler ${ }^{\circledR} 4$ was used for 3D visualization of results.
Table 2: Main data of the building of the case study.

\begin{tabular}{|l|l|l|}
\cline { 2 - 3 } \multicolumn{1}{l|}{} & Two-storey building & Wine-ageing room \\
\hline Width & $9.8 \mathrm{~m}$ & $5.6 \mathrm{~m}$ \\
\hline Length & $\begin{array}{l}20.5 \mathrm{~m} \\
\text { (above ground) } \\
+5.6 \mathrm{~m} \text { (above cellar) }\end{array}$ & $9.8 \mathrm{~m}$ \\
\hline Height & $\begin{array}{l}7.3 \mathrm{~m} \text { (borders) } \\
8.4 \mathrm{~m} \text { (centre) }\end{array}$ & $2.6 \mathrm{~m}$ (underground) \\
\hline Walls & $\begin{array}{l}25.0 \mathrm{~cm} \text { thick } \\
\text { masonry }\end{array}$ & $\begin{array}{l}25.0 \mathrm{~cm} \text { thick } \\
\text { masonry }\end{array}$ \\
\hline Floor & $\begin{array}{l}30.0 \mathrm{~cm} \text { hollow } \\
\text { concrete slab }\end{array}$ & $20.0 \mathrm{~cm}$ concrete slab \\
\hline Ceiling & - & $\begin{array}{l}30.0 \mathrm{~cm} \text { hollow } \\
\text { concrete slab }\end{array}$ \\
\hline $\begin{array}{l}\text { Air } \\
\text { conditioning }\end{array}$ & $\begin{array}{l}\text { Heating and natural } \\
\text { ventilation }\end{array}$ & Natural ventilation \\
\hline
\end{tabular}




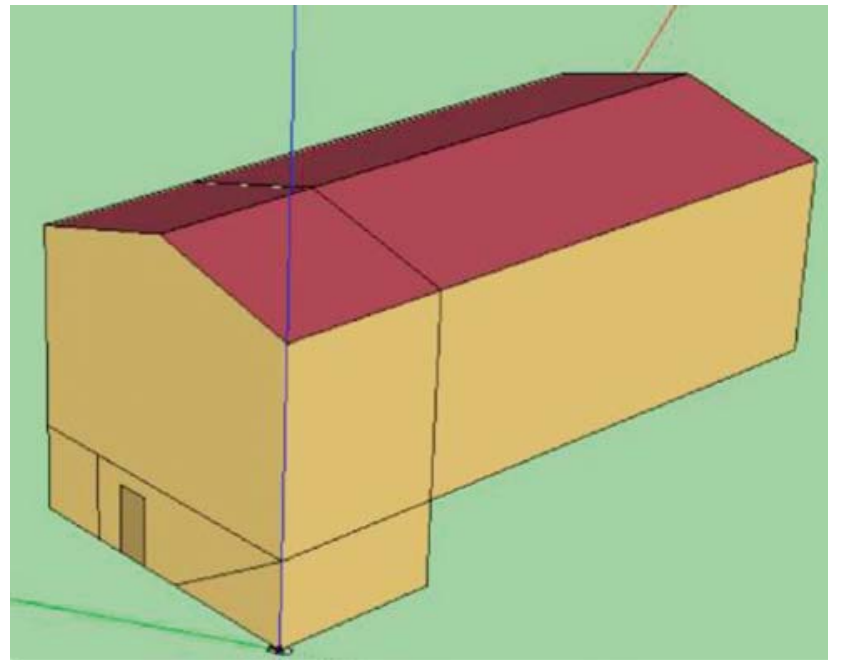

Figure 1: Schematic three-dimensional representation of the building case study (Barbaresi et al., 2014).

Table 3: Weather and indoor data for the case study.

\begin{tabular}{|l|l|l|l|}
\cline { 2 - 4 } \multicolumn{1}{c|}{} & $\mathrm{T}_{\mathrm{m}}\left({ }^{\circ} \mathrm{C}\right)$ & $\mathrm{A}\left({ }^{\circ} \mathrm{C}\right)$ & Phase shift (days) \\
\hline Weather data & 15.0 & 15.5 & $\mathrm{t}_{\mathrm{T} 0}=10.0$ \\
\hline Two-storey building & 21.4 & 9.9 & $\mathrm{a}=150.0, \mathrm{~b}=150.0$ \\
\hline Wine-ageing room & 18.3 & 5.3 & $\mathrm{a}=150.0, \mathrm{~b}=150.0$ \\
\hline
\end{tabular}

logna, Italy. A set of sensors inside the building allowed the calculation of internal ambient data. The two-storey building is heated during the winter season, while there is no mechanical cooling during the summer season, so its mean temperature is definitely higher than outdoors. As for the wine-ageing room, only natural ventilation exists and the internal temperature values depend on the ground thermal behaviour surrounding the underground space.

Considering the phase shift, $10^{\text {th }}$ of January is the day of yearly minimum temperature for the case study. On the other hand, the values of time lead and time lag for the building and the underground room have been calculated by matching temperature waves obtained starting from heat transfer of Equation 2 and multiyear experimental measures of internal temperature, with four sensors inside the wine cellar and two sensors below the building and beside the cellar (Tinti et al., 2015).

Phase shift applied is visible in the heat transfer waves of Figure 3 in next section.

To the depth of the cellar basement, underground is composed prominently by low moist clay. The complete litho-stratigraphy up to $50.0 \mathrm{~m}$ is shown in Figure 2. At the depth of $18 \mathrm{~m}$ from the surface, an aquifer is present. Data sources are the geological investigations related to the installation of temperature sensors, the technical sheets about a nearby well $25.0 \mathrm{~m}$ deep and additional information gathered by Geological Survey of Emilia Romagna Region.

A multiyear measurement campaign of temperature and moisture has been conducted on the building, through

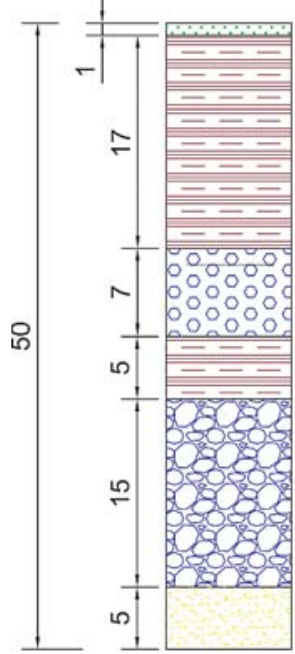

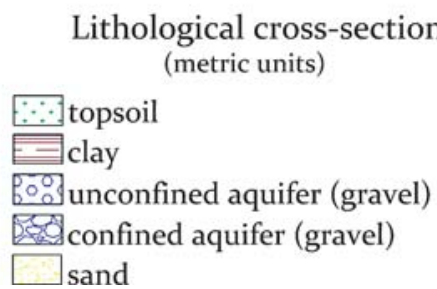

Figure 2: Lithological cross-section for the case study. Measures in meter.

the use of climatic sensors of type PCE-HT71 and a weather station model PCE-FWS20.

Additional temperature measurements were conducted on groundwater from an existing well near the building.

The set of measurements allowed to collect multiyear data sets of the following parameters: external climatic conditions, indoor temperature and moisture of the heated building, indoor temperature and moisture of the cellar, underground temperature at different locations and depth, from 0.1 to $6.0 \mathrm{~m}$ below the ground level, around and below the heated building and the cellar (Barbaresi et al., 2014; Tinti et al., 2014; Tinti et al., 2015; Barbaresi et al., 2015; Benni et al., 2016).

The underground shows a vertical variability of geological conditions that influences the temperature. Thermal conductivity $l$ and thermal diffusivity $a$ are interrelated with each other and they are influenced by lithostratigraphy.

Mean values of thermal conductivity and diffusivity of different layers should be calculated or estimated; they can be obtained by in situ or laboratory tests or, once knowing the geology of the investigated zone, by extrapolation from substantial bibliography, such as the tables of the technical norms.

Table 4: Site-specific values derived by the experimental analysis conducted.

\begin{tabular}{|l|l|l|}
\hline Lithotype & $a\left(\mathrm{~m}^{2} / \mathrm{d}\right)$ & $l(\mathrm{~W} /(\mathrm{m} \cdot \mathrm{K}))$ \\
\hline Low moist clay & $0.0288^{*}$ & $0.5^{*}$ \\
\hline Saturated gravel & $0.0648^{* *}$ & $1.8^{* *}$ \\
\hline Moist clay & $0.0540^{* *}$ & $1.0^{* *}$ \\
\hline Saturated gravel & $0.0648^{* *}$ & $1.8^{* *}$ \\
\hline Moist sand & $0.0864^{* *}$ & $2.4^{* *}$ \\
\hline
\end{tabular}

* Calculated values obtained by the experimental campaign of measurements (Tinti et al., 2014).

** Indicative values of thermal properties according to Italian Technical Norm UNI 11466 (UNI, 2012). 
For the specific case study, the values of thermal diffusivity and thermal conductivity have been extrapolated through the multiyear measurement campaign up to a depth of $6 \mathrm{~m}$. These values were later additionally verified by a Thermal Response Test (TRT) performed on a geothermal basket installed on site (Ferrari et al., 2016).

Table 4 summarizes the values of the interest variables for temperature assessment related to the case study, together with the data source.

The value of geothermal heat flow $\left(h=0.03 \mathrm{~W} / \mathrm{m}^{2}\right)$ for the case study area was taken from the Italian Geothermal Resources National Inventory (UNMIG, 2010) and confirmed by the update of the global map of heat flow of solid Earth by Davies (2013).

\section{Results and discussions}

The space-time varying heat transfer expressed by Equation 2 can be applied to any interface between the building, cellar and ground. The heat transfer per surface $(f)$ waves for the different possible interfaces between the building and the ground are exposed in Figure 3.

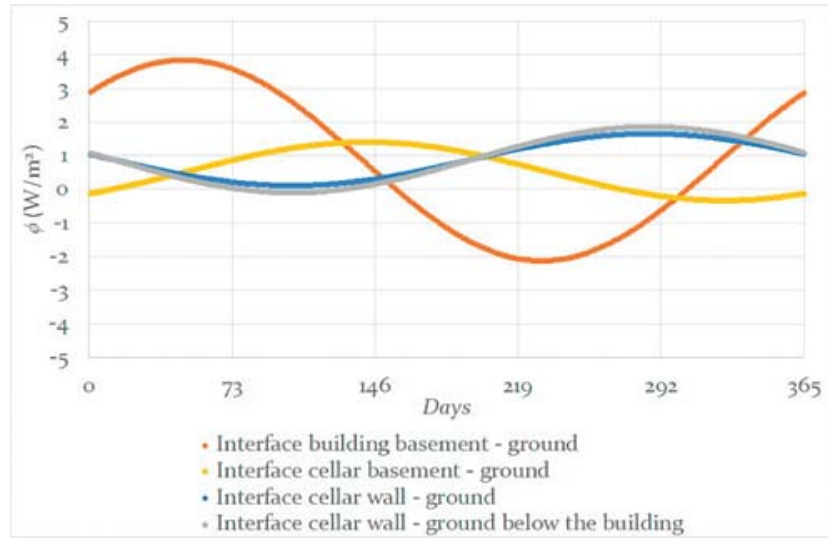

Figure 3: Heat transfer at the different interfaces of the building with the ground.

The heat transfer wave model between the building basement and the ground differs from the wave model between the cellar and the ground. The underground cellar dampens the amplitude and causes a translation of heat transfer peaks, while the mean value keeps practically constant around $0.5 \mathrm{~W} / \mathrm{m}^{2}$. More in detail:

- the heat transfer between the building basement and the ground is characterized by high amplitude (3.0 $\mathrm{W} / \mathrm{m}^{2}$ ) and phase shift corresponding to the values reported in Table 3,

- the heat transfer between the cellar basement and the ground is dampened (amplitude $0.5 \mathrm{~W} / \mathrm{m}^{2}$ ), with a reduction of phase shift caused by the thermal inertia contribution of the entire cellar,

- the heat transfer between the cellar wall and the ground shows the same amplitude of the previous case, with a different phase shift caused by the partial thermal inertia contribution of the cellar.

In agreement with the heat losses of the building via the ground, the entire underground temperature behaviour affected by the presence of the building has been created, by the use of the models reported in Table 1 and the data presented in Table 2 and Table 3.

Figure 4 shows the three-dimensional thermal tomographic mapping in the underground for 4 months, around and below the building. For the $3 \mathrm{D}$ visualization, the software package Voxler ${ }^{\circledR} 4$ was used (Golden Software, 2015). The input data to the software Voxler ${ }^{\circledR} 4$ for $3 \mathrm{D}$ visualization are the result of calculation performed by Tzone 1.0, having a grid spacing of $0.2 \mathrm{~m}$ up to the cellar depth $(3.0 \mathrm{~m})$ and a larger grid spacing of $1.0 \mathrm{~m}$ from the cellar depth to the bottom $(50.0 \mathrm{~m})$.

The four pictures visualize a $3 \mathrm{D}$ section cut along the $x$ and $y$ borders of the building, excluding the wine cellar (which will be detailed in Figure 5 and Figure 6). The pictures show how subsoil temperature changes over time, due to the influence of seasonal variation and building presence. The parameters of internal and external waves (average, amplitude and phase shift, see Table 3) determine the shape of the subsoil temperature distribution. In January, the surface temperature is lower than the subsoil temperature, and then it increases with different behaviour from the centre to the external borders of
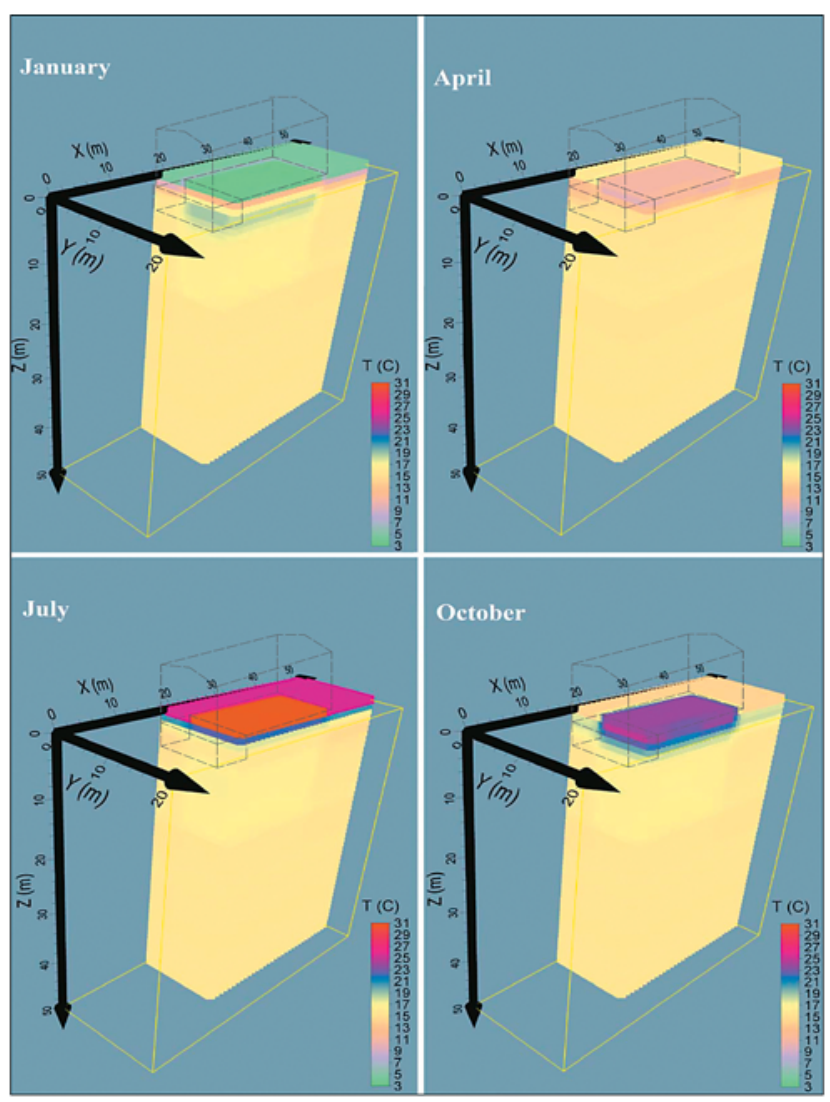

Figure 4: Three-dimensional reconstruction of underground temperature distribution. The temperature variation throughout the year is presented in four represented periods. 
the building. Below the building, in the shallow layers (3.0 to $10.0 \mathrm{~m}$ depth), the temperature is around $3.0^{\circ} \mathrm{C}$ higher than below the free surface. Moving deeper, the difference tends to disappear keeping around $0.3{ }^{\circ} \mathrm{C}$ in correspondence with the first saturated layers $(18.0 \mathrm{~m}$ depth). In July, the surface behaviour is opposite to January, with subsoil temperature lower than normal in the shallow layers. With respect to the winter season, the influence of the building on subsoil temperature values is less emphasized $\left(1.0{ }^{\circ} \mathrm{C}\right.$ colder than below the free surface). This is caused by the specific thermal energy needs of the building, with consequent use of mechanical heating in the winter season and natural cooling in the summer season. This makes temperature variation unbalanced throughout the year, with a subsequent temperature rise in the subsurface (estimated around $0.2-$ $0.3{ }^{\circ} \mathrm{C}$ ).

April and October are intermediate months, with subsequent intermediate behaviour. Because of building thermal inertia, phase shift plays an important role for the very surface layers ( 0.0 to $2.0 \mathrm{~m}$ depth), with temperature differences, caused by the building presence, over $5.0^{\circ} \mathrm{C}$ in April and even over $10.0^{\circ} \mathrm{C}$ in October.

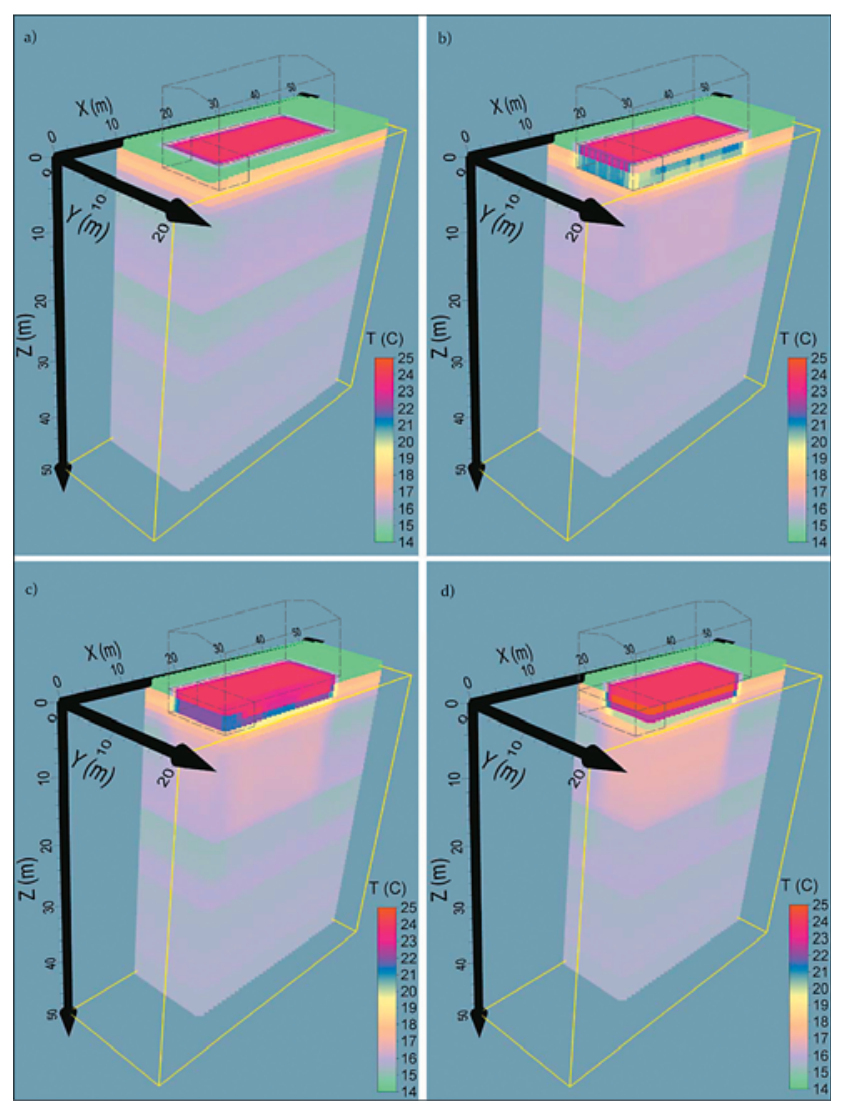

Figure 5: Three-dimensional reconstruction of underground temperature distribution. Temperature space variation around and below the building for four $3 \mathrm{D}$ views of underground in the month of October: undisturbed underground (a), underground beside the building (b), underground cellar thermal impact (c), building thermal impact (d).
These effects are strongly dampened at deeper layers, tending to disappear at greater depths.

Figure 5 presents a series of 3D temperature sections for the month of October, in order to better appreciate the space differences of thermal impact to the ground for different parts of the building. The sections show the vertical distribution of temperature from far, near and below the building, with a focus on the wine cellar thermal impact.

The limits of temperature scale have been narrowed with respect to Figure 4, and this allows for a finer visualization of temperature differences between the layers. By comparing (a) with (b), (c) and (d), it is possible to distinguish four zones of temperature variation along the depth:

- the first zone, from the building basement up to the depth of the wine cellar (around $3.0 \mathrm{~m}$ below surface), with consistent temperature variations according to the location (with a maximum of $10.0^{\circ} \mathrm{C}$ difference between the building basement and the free surface and a minimum of $4.0{ }^{\circ} \mathrm{C}$ difference between the inside of the wine cellar and the free surface),

- the second zone, below $3.0 \mathrm{~m}$ down to $5.0 \mathrm{~m}$, with a variation around $2.0-3.0{ }^{\circ} \mathrm{C}$ from normal underground behaviour,

- the third zone, below $5.0 \mathrm{~m}$ down to the aquifer depth, where temperature differences with the surroundings from 1.0 to $0.5{ }^{\circ} \mathrm{C}$ are visible, tending to disappear with depth,

- finally, the fourth zone, in correspondence with the aquifer, with a temperature increase of $0.3{ }^{\circ} \mathrm{C}$ with respect to groundwater temperature.

The presence of the building strongly affects the underground thermal behaviour, causing a temperature rise which keeps over time. The temperature rise dampens from the borders of the building to the undisturbed ground, in different ways according to the land cover and urbanization, which influences both the heat transfer and the shading coefficient for surface layers. Along the vertical depth, the temperature wave is dampened up to reach the neutral zone, where the temperature amplitude is null. In the specific area of the case study, according to the maximum investigation depth, the presence of the geothermal gradient does not significantly affect temperature; this is due to the low value of geothermal heat flow, which is almost negligible for the scale of work considered.

On the contrary, the different geological and hydrogeological layers are visible in terms of temperature modification (see Lithological cross - section of Figure 2 for comparison with the 3D temperature layout of Figure 4 and Figure 5).

Regarding the heat losses from the building, shown in Figure 3, the higher contribution comes from the interface between the heated building and the ground, where- 
as the presence of the cellar dampens the thermal impact of the surface building on ground temperature.

According to the calculation performed, it is expected that groundwater temperature rises a few decimals with respect to natural temperature values of the investigation area. Such a variation should tend to disappear below the cellar, because of the smoothed effect of the thermal impact of the building. The annual average groundwater temperature keeps constant around $15^{\circ} \mathrm{C}$ and no thermal signals of the presence of the building could be appreciated. This is probably due to the relatively low surface occupied by settlements with respect to the croplands and grasslands, being the case study is located in a rural area. Moreover, according to the hydrogeology information of Geological Survey of Emilia Romagna, the case study is placed in the alluvial fan of the Sillaro River, and the aquifer is classified as one of the extensive and highly productive aquifers. Therefore, it is also probable that the high groundwater movement dissipates the heat build-up from the surface.

The temperature inside and around the wine cellar is affected by major space-time variations, because of multiple discontinuity lines, represented by cellar borders.
Figure 6 shows vertical temperature profiles of different locations around and within the wine cellar, for four characteristic months of the year.

Temperature within the cellar is considered uniform in space and its value differs from both temperature below the free surface and temperature below the building. The heat transfer via the ground when crossing the unheated space is related to the parameters of a wineageing room reported in Table $\mathbf{3}$, and it results in the specific temperature behaviour visualized in Figure 6.

\section{Conclusions}

This paper presented a three-dimensional reconstruction of subsoil temperature affected by the presence of a building in a rural area. The models used in the paper were previously calibrated on temperature measurements realized in a multiyear campaign performed in the period 2013-2015. The three-dimensional visualization allowed to define how variations of geometry and materials affect, with different impact, underground temperature below and next to the building. The calculation of temperature field in the zone below the building was per-

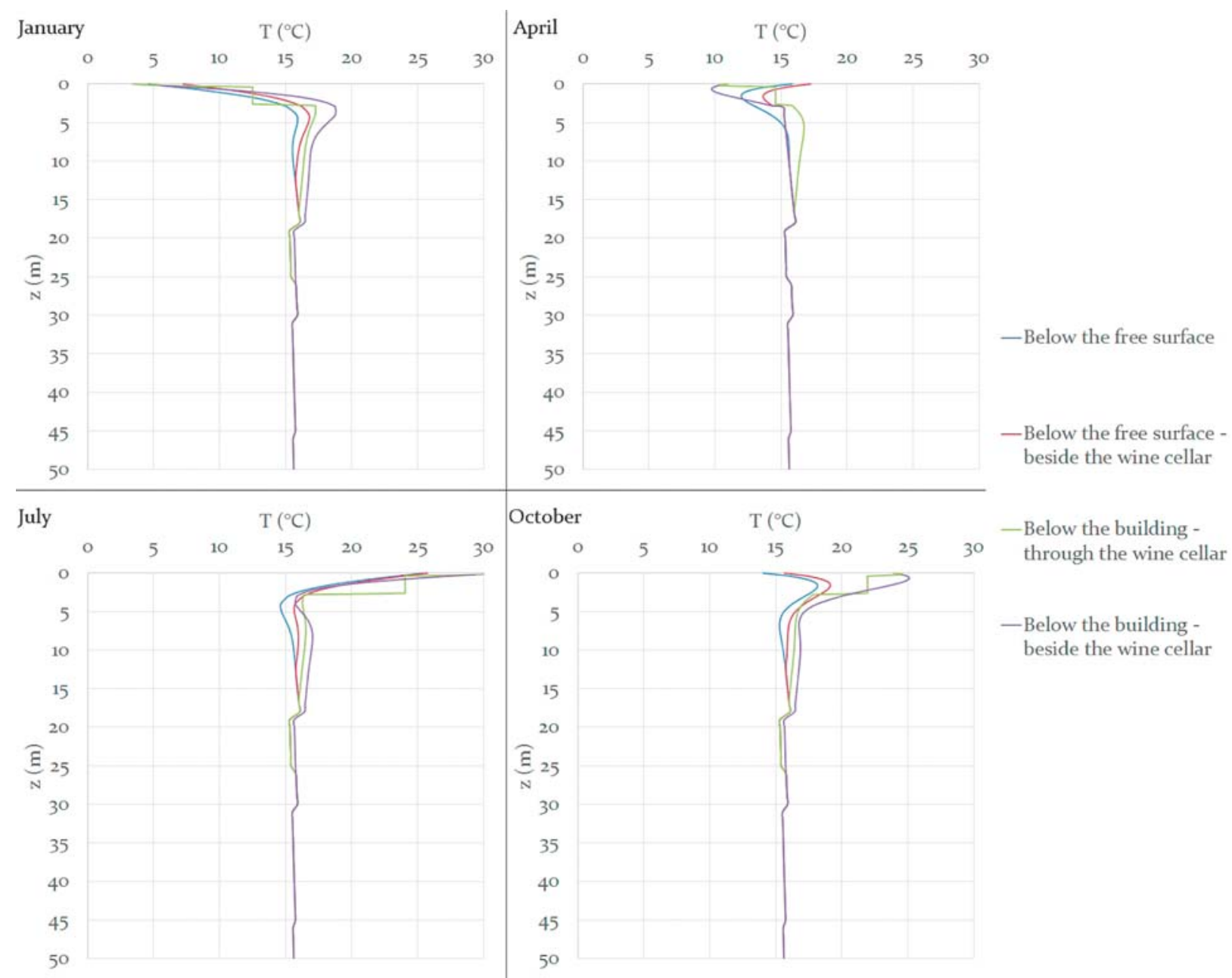

Figure 6: Underground temperature behaviour for the area influenced by the presence of the wine cellar, represented for four specific locations and in four characteristic months. 
formed both for the underground layers affected by ambient temperature variations (strongly dampened by the presence of the building itself) and for the deep layers, where temperature is supposed to keep constant over time.

Results quantify the impact of the single building on the underground: temperature increases/decreases from 2.0 to $5.0^{\circ} \mathrm{C}$ at the shallow layers, down to some decimals of degrees Celsius at the first saturated layer, 18.0 $\mathrm{m}$ deep. The impact can strongly vary in space and time, based on the presence of unheated underground spaces, such as the wine-ageing room of the case study. Due to the prominent use of heating instead of cooling, an unbalance of heat throughout the year is reflected in the underground thermal behaviour. For the case study considered, the temperature rise was evidenced. Being located in a rural area, the impact of the building on groundwater temperature is limited and does not influence the surroundings.

The correct and accurate understanding of underground thermal behaviour and estimation of temperature profiles in the presence of buildings could have a relevant impact on the design of air conditioning systems for underground spaces and on the shallow geothermal potential assessment of a determined geographical zone. In the particular case of highly urbanized areas, the multiple thermal impacts of many nearby buildings would transpose the Urban Heat Island effect in the subsoil, with a consequent increase of ground and groundwater temperature. This phenomenon has double facets: on one side, it is considered as thermal pollution caused by the human presence, which affects ecosystems; on the other side, it could enhance the technical and economic convenience of shallow geothermal exploitation for the heating of buildings, and so helping to reduce the carbon footprint of urban areas. Further analysis on the topic is scheduled by the authors.

\section{Acknowledgments}

The research work presented in this paper has been supported by the research project GEOTeCH (www. geotech-project.eu), co-funded by the European Community Horizon 2020 Program for European Research and Technological Development (2014-2020).

Moreover, authors wish to thank the farm winery "Branchini 1858", Toscanella di Dozza (BO), Italy, for the availability and the collaboration in the research concerning the phases of monitoring and experimental trials.

\section{References}

Adam D. and Markiewicz R. (2009): Energy from earth-coupled structures, foundations, tunnels and sewers. Géotechnique, 59, 3, $229-236$.

Allen A., Milenic D. and Sikora P. (2003): Shallow gravel aquifers and the urban 'heat island' effect: a source of low enthalpy geothermal energy. Geothermics, 32, $569-578$.
Arola T. and Korkka-Niemi K. (2014): The effect of urban heat islands on geothermal potential: examples from Quaternary aquifers in Finland. Hydrogeology Journal, 22, 1953 - 1967, doi: 10.1007/s10040-014-1174-5.

Baggs S.A. (1985): Remote prediction of ground temperature in Australian soils and mapping its 570 distribution, Solar Energy, 30, 351-366, doi:10.1016/0038-092X(83)90189-5.

Barla M. and Perino A. (2015): Energy from geo-structures: a topic of growing interest. Environmental Geotechnics, 2, 1, 3-7.

Bandos T.V., Montero A., Fernandez E., Santander J.L.G., Isidro J.M., Perez J., Fernandez de Cordoba P. J. and Urchueguía J.F.(2009): Finite line-source model for borehole heat exchangers: effect of vertical temperature variations. Geothermics, 38,2, 263-270.

Barbaresi A., Torreggiani D., Benni S. and Tassinari P. (2014). Underground cellar thermal simulation: definition of a method for modelling performance assessment based on experimental calibration, Energy Build., 76, 363-372, http://dx.doi.org/10.1016/j.enbuild.2014.03.008.

Barbaresi A., Torreggiani D., Benni S. and Tassinari P. (2015). Indoor air temperature monitoring: A method lending support to management and design tested on a wine-aging room, Building and Environment, 86, $203-210$.

Benni S., Tinti F., Barbaresi A., Ferrari M., Bruno R., Torreggiani D. and Tassinari P. (2016): Experimental models of underground temperature for decision making in wine cellar design. Proceedings of 44th International Symposium on Agricultural Engineering, 487-498.

Bornstein R.D. (1968): Observation of the Urban Heat Island effect in New York City. Journal of Applied Meteorology, $7,575-581$.

Claesson J. and Hagentoft C-E. (1991): Heat loss to the ground from a building - I. General theory. Building and Environment, 26(2), 95-208.

Davies J.H. (2013): Global map of solid Earth surface heat flow. Geochemistry, Geophysics, Geosystems, 14, 10, 4608 - 4622, doi 10.1002/ggge.20271.

Ferguson G. and Woodbury A.D. (2004): Subsurface heat flow in an urban environment. J. Geophys. Res., 109, DOI: 10.1029/2007GL032324.

Ferguson G. and Woodbury A. D. (2007): Urban heat island in the subsurface. Geophys. Res. Lett., 34, 4, DOI: 10.1029/ 2007 GL032324.

Ferrari, M., Barbaresi, A., Tinti, F., Brunelli, D., Benni, S., Verdecchia, A., ... Tassinari, P. (2016): Performance evaluation of a homemade cylindrical basket heat exchanger, by a multi-sensors monitoring campaign, Proceedings of European Geothermal Energy Conference 2016, Strasbourg, pp. 9.

Geological Survey of Emilia Romagna. URL: http://ambiente. regione.emilia-romagna.it/geologia.

Hagentoft C-E and Claesson J. (1991): Heat loss to the ground from a building - II. Slab on the ground. Building and Environment, 26(4), 395-403.

Headon J., Banks D., Waters A. and Robinson V. K. (2009): Regional distribution of ground temperature in the Chalk aquifer of London UK Q. J. Eng. Geol. Hydrogeol., 42, 313-23. 
Huang S., Taniguchi M., Yamano M. and Wang C. H. (2009): Detecting urbanization effects on surface and subsurface thermal environment-a case study of Osaka Sci. Total Environ., 407, 3142-52.

ISO 13370 (2007): Thermal performance of buildings - Heat transfer via the ground - Calculation methods. ISO International Standards, www.iso.org, pages 48.

Kurevija T. and Vulin D. (2010): Determining undisturbed ground temperature as part of shallow geothermal resources assessment. Rudarsko-geolosko-naftni zbornik, 22, 27-36.

Kusuda T. and Achenbach P. (1965): Earth temperature and thermal diffusivity at selected stations in the United States, ASHRAE Transactions, 71, 61-75.

Landsberg, H. E. (1981): The Urban Climate, Int. Geophys. Ser., 28.

Mandanici E., Conte P. and Girelli V.A. (2016). Integration of Aerial Thermal Imagery, LiDAR Data and Ground Surveys for Surface Temperature Mapping in Urban Environments. Remote Sensing, 8/10, p. 19, doi:10.3390/ rs8100880.

Mazarron F.R., Cid-Falceto J. and Canas I. (2012): Ground thermal inertia for energy efficient building design: a case study on food industry. Energies, 5, 227-242.

Menberg K., Bayer P., Zosseder K., Rumohr S. and Blum P. (2013): Subsurface urban heat islands in German cities. Science of the Total Environment, 442, 123-133.

Popiel C.O., Wojtkowiak J. and Biernacka B. (2001): Measurements of temperature distribution in ground. Exp. Therm. Fluid Sci., 25, 301-309, http://dx.doi.org/10.1016/ S0894-1777(01)00078-4.
Rees S.W., Adjali M.H., Zhou Z., Davies M. and Thomas H.R. (2000): Ground heat transfer effects on the thermal performances of earth-contact structures. Renewable and Sustainable Energy Reviews, 4, 213-265.

Taniguchi M, Uemura T. and Jago-on K. (2007): Combined effects of urbanization and global warming on subsurface temperature in four Asian cities Vadose Zone J., 6, 591596 doi:10.2136/vzj2006.0094.

Tinti F., Barbaresi A., Benni S., Torreggiani D., Bruno R. and Tassinari P. (2014): Experimental analysis of shallow underground temperature for the assessment of energy efficiency potential of underground wine cellars. Energy and Buildings, 80, 451-460.

Tinti F., Barbaresi A., Benni S., Torreggiani D. Bruno R., and Tassinari P. (2015): Experimental analysis of thermal interaction between wine cellar and underground. Energy and Buildings, 104, 275-286.

UNI 11466:2012 (2012) - Sistemi geotermici a pompa di calore - Requisiti per il dimensionamento e la progettazione.

UNMIG (Ufficio Nazionale Minerario per gli idrocarburi e le georisorse) (2010): Inventario delle risorse geotermiche nazionali, conseguente alle disposizioni del Decreto Legislativo 11 febbraio 2010, n. 22, http://unmig.mise.gov.it/ unmig/geotermia/inventario/inventario.asp.

Voxler®4 (2015) - Quick Start's Guide.

Yalcin T and Yetemen O (2009): Local warming of groundwaters caused by the urban heat island effect in Istanbul, Turkey. Hydrogeol. J., 17, 1247-1255.

Zhu K., Blum P., Ferguson G., Balke K.-D. and Bayer P. (2010) The geothermal potential of urban heat islands. Environmental Research Letters, 5/4, p. 5.

\section{SAŽETAK}

\section{Eksperimentalna kalibracija modela podzemnih transfera topline ispod vinskih građevina u seoskim područjima}

Površinske temperature i hidrogeološki uvjeti ključni su parametri u mnogim inženjerskim primjenama poput izgradnje podruma i drugih podzemnih prostorija te kod procjene plitkoga geotermalnog potencijala. Međutim, teško je otkriti prirodne, tj. izvorne, toplinske uvjete, poglavito u plitkim, podzemnim, gradskim područjima. Razlog tomu je ljudski utjecaj. Stoga procjena toplinskih varijabli u takvim uvjetima postaje sve važnija, jer raste i uporaba geotermalne energije, posebice kao obnovljivoga izvora. Cilj rada bio je prikazati trodimenzionalni model takvih uvjeta, kalibriran eksperimentalnim podatcima. Tako je opisano ponašanje topline u podzemlju pod utjecajem građevina u odabranome seoskom području Italije. Temperaturne varijacije u prostoru i vremenu ovisile su o površinskim stijenama (i/ili tlu), klimi i svojstvima same građevine. Svi ti parametri razmatrani su unutar modela sezonskih promjena temperatura. Rezultati modela u područjima niske urbanizacije neizravno upućuju kako promatrani parametri imaju veliku važnost u visoko urbaniziranim područjima. Nadalje takvi rezultati mogu se uključiti u buduće modele plitkoga podzemlja i razmjenjivača topline te unaprijediti kako njih, tako i opću uporabu geotermalne energije.

\section{Ključne riječi}

toplinski utjecaj građevina, potpovršinska temperatura, plitka geotermalna energija, toplinski tok unutar tla 